Click www.researchjournal.co.in/online/subdetail.html to purchase.

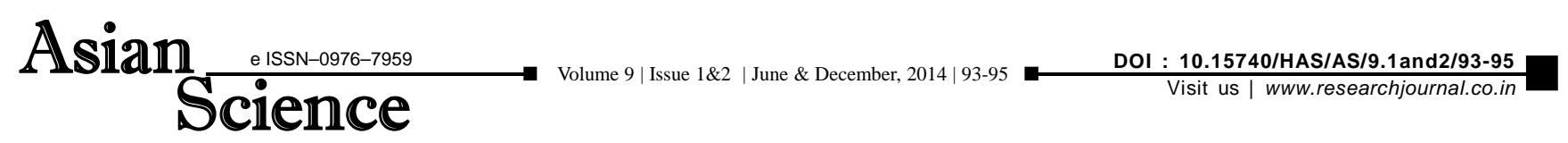

RESEARCH NOTE

\title{
Early childhood care and education in India: a contextual analysis
}

\author{
AMARESH CHANDRA SAHOO \\ Department of Political Science, Ravenshaw University, CUTTACK (ODISHA) INDIA
}

Key Words : Childhood care, Education

View point paper : Sahoo, Amaresh Chandra (2014). Early childhood care and education in India: a contextual analysis. Asian Sci., 9 (1\&2): $93-95$. 